\title{
MICROBIAL TRANSFORMATION OF 2,5 DIHYDROXYCINNAMIC ACID BY ASPERGILLUS NIGER AND RHIZOPUS ORYZAE
}

\author{
Mohammed Hosny ${ }^{1}$; Zeinab Abdel-Aziz ${ }^{2}$; Mahmoud M. El-aasser ${ }^{3}$; and Monira Zhran ${ }^{2}$ \\ ${ }^{\mathbf{1}}$ Department of Pharmacognosy, Faculty of Pharmacy, Al-Azhar University, Cairo, Egypt. \\ ${ }^{2}$ Department of Microbiology, Faculty of Science (Girls), Al-Azhar University, Cairo, Egypt. \\ ${ }^{3}$ Regional Center of Mycology, Al-Azhar University, Cairo, Egypt.
}

\begin{abstract}
2,5-dihydroxy cinnamic acid (1), when fermented with fungal culture, Rhizopus oryzae RCMB 014002 gave mainly two metabolites; 2,5-dihydroxy cinnamoyl alcohol (Cin$\boldsymbol{R M - 1 )}$ and 2-Hydroxy-4,5-dimethoxy cinnamoyl alcohol (Cin-RM-2). Aspergillus niger RCMB002007, however, transformed 2,5-dihydroxy cinnamic acid (1), into a major metabolite;2-hydroxy-5-methoxy cinnamic acid (Cin-AM-3). The structures of the metabolic products were elucidated by means of spectroscopic data. The significance of the metabolites as antioxidants using DPPH radical scavenging assay and lipid peroxidation assay by thiobarbituric acid-reactive substances (TBARS) method using rat tissue homogenates in relation to their structure was discussed.
\end{abstract}

Key words: Microbial transformation, 2,5 dihydroxy-cinnamic acid, Aspergillus niger, Rhizopus oryzae, antioxidant activities.

\section{INTRODUCTION}

Cinnamic acid, the deaminated product of phenyl-alanine in plant tissue, a frequent first step is the elimination of ammonia from the side-chain to generate the appropriate trans (E) cinnamic acid. Other cinnamic acids are obtained by further hydroxylation and methylation reactions, sequentially building up substitution patterns typical of shikimate pathway metabolites, i.e. an ortho oxygenation pattern. Cinnamic acid has a long history of human use as a component of plant-derived scents and flavorings (Hoskins, 1984). Cinnamic acid is also an auxin, a class of plant hormones regulating cell growth and differentiation (Thiman, 1969). Several biological activities including antioxidant, anti-inflammatory, cytotoxic, hepatoprotective, immunosuppressive, anti-cholesterolemic, antimicrobial and antiviral activities have been attributed to this class of compounds (Natella et al., 1999; Kim et al., 2005; Miles et al., 2005; Fernández-Martínez et al., 2007; Gravina et al., 2011; Prateek , 2011; Luana Dalbem et al., 2012) .

Biotransformations are useful techniques for producing medicinal and agricultural chemicals from both active and inactive materials. These reactions are an important route for introducing chemical functions into inaccessible sites of molecules and thereby to produce rare structures. The biotransformation reactions can involve high degree of regio- and stereospecificity and require mild reaction conditions. Many researchers have reported the production of drug metabolites using microbial biotransformations (Grogan, 2009). The use of microorganisms may be utilized as models of drug metabolism to predict the fate of xenobiotics in mammalian systems (Smith and Rosazza, 1982), since this method often gives sufficient quantities of metabolites, complete chemical structure and pharmacological activities could be determined. In our ongoing research on microbial transformation of phenolic compounds (Hosny et al., 2001), 2,5-dihydroxycinnamic acid (1), was screened using 11 different microorganisms. Of the organisms which effected transformation, scale up studies was carried out with selected cultures to isolate the maximum number of metabolites 
in reasonable yields. Structure elucidation of the isolated metabolites and their possible impact on the antioxidant activity in relation to structure are reported herein.

\section{EXPERIMENTAL SECTION}

\section{General Experimental Procedures:}

Infra-red spectra were recorded using a Bruker Tensor 27 FT-IR (Bruker OpticsGmbH, Ettlingen, Germany) spectrometer with $\mathrm{KBr}$ pellets and UV spectra were determined JASCO V-520 UV/VIS spectrophotometer. JEOL NMR spectrometer operating at $500 \mathrm{MHz}$ for ${ }^{1} \mathrm{H}-\mathrm{NMR}$ spectra were obtained in $\mathrm{CDOD}$ or $\mathrm{CDCl}_{3}$ using TMS as an internal standard with the chemical shifts expressed in $\delta$ and coupling constants $(J)$ in Hertz. El-MS (VG-ZAB-H F), X-mass (158.64, 800.00) (VGA analytical, Inc.). Silica gel column chromatography (CC) was performed on silica gel 60 (E. Merck, Darmstadt, Germany). TLC was carried out on pre-coated silica gel $60 \mathrm{~F}_{254}$ (Merck) plates. Developed chromatograms were visualized by spray with $1 \%$ vanillin $/ \mathrm{H}_{2} \mathrm{SO}_{4}$, followed by heating at $100^{\circ} \mathrm{C}$ for $3 \mathrm{~min}$. TLC plates were developed with solvent systems: A (EtOAc:Hexane, 1:1, v:v) or B $\left(\mathrm{CHCl}_{3}: \mathrm{MeOH}, 8.5: 1.5, \mathrm{v}: \mathrm{v}\right)$. 2,5-dihydroxy cinnamic acid (1), used in this study was kindly given as a gift from Prof. Mohammed Hosny, Al-Azhar University, Faculty of Pharmacy, Pharmacognosy Department, Cairo, Egypt. The purity of the substrates was confirmed by TLC and ${ }^{1} \mathrm{H}-\mathrm{NMR}$.

\section{Microorganisms:}

Cunninghamella elegans (RCMB 012001), Cunninghamella echinulata (RCMB 012002), Mucorrouxii (RCMB 015004), Absidia corymbifera (RCMB 051002), Penicillium notatum (RCMB 001023), Penicillium aurantiogriseum (RCMB), Candida albicans (RCMB 005004), Rhodotorula glutins (RCMB 028001), Rhizopus oryzae (RCMB 014002), Aspergillus niger (RCMB002007(5)001002(2) and Aspergillus flavus RCMB002002(3)were obtained from Mycology and Biotechnology Center, Al-Azhar University, Cairo, Egypt.

\section{Analytical-Scale Biotransformation of 2,5dihydroxycinnamic acid (1):}

A two-stage fermentation protocol (Hosny, and Rosazza 1999), was used for analytical and preparative scale formation of (1) metabolites. For screening experiments, solid cultures kept on either potato dextrose agar or sabaraud maltose agar of the following organisms was used: Cunninghamella elegans (RCMB 012001), Cunninghamella echinulata (RCMB 012002), Mucorrouxii (RCMB 015004), Absidia corymbifera (RCMB 051002), Penicillium notatum (RCMB 001023), Penicillium aurantiogriseum (RCMB), Candida albicans (RCMB 005004), Rhodotorula glutins (RCMB 028001), Rhizopus oryzae (RCMB 014002), Aspergillus niger (RCMB002007(5)001002(2) and Aspergillus flavus RCMB002002(3). Each culture was used separately to inoculate $100 \mathrm{ml}$ flasks containing one fifth of their volume of the following medium: $5 \%(\mathrm{w} / \mathrm{v})$ soybean meal, $0.5 \%$ yeast extract, $0.5 \% \mathrm{NaCl}, 0.5 \% \mathrm{~K}_{2} \mathrm{HPO}_{4}$, and $2 \%$ dextrose per $1 \mathrm{~L}$ of distilled water, adjusted to $\mathrm{pH} 7.0$ with $6 \mathrm{~N} \mathrm{HCl}$, was autoclaved at $121^{\circ} \mathrm{C}$ for $15 \mathrm{~min}$. Analytical incubations were conducted in $25 \mathrm{~mL}$ of sterile medium held in $125 \mathrm{~mL}$ stainless steel-capped Delong culture flasks that were incubated for $72 \mathrm{~h}$ at $28^{\circ} \mathrm{C}$ on a rotary shaker operating at $250 \mathrm{rpm}$. A $10 \%$ inoculum derived from $72 \mathrm{~h}$ old stage I cultures was used to initiate stage II cultures, which were incubated for $24 \mathrm{~h}$ more before receiving $5 \mathrm{mg}$ of 1 in Tween $80-\mathrm{H}_{2} \mathrm{O}(0.5 \mathrm{~mL} ; 1: 3 \mathrm{~V} / \mathrm{V})$, and incubations was continued. Substrate controls consisted of sterile medium and substrate incubated under the same conditions but without microorganism. Samples of $3 \mathrm{~mL}$ were withdrawn for analysis at 24, 48, 72, and $144 \mathrm{~h}$ after substrate addition, extracted with $1 \mathrm{~mL}$ of EtOAc: $n$-BuOH (9:1). The organic layer was separated from aqueous medium by 
centrifugation at 1,200 $\mathrm{x} g$ in a desktop centrifuge and $60 \mu \mathrm{L}$ samples were spotted onto TLC plate developed with solvent system using $\mathrm{CH}_{2} \mathrm{Cl}_{2}: \mathrm{MeOH}: \mathrm{CH}_{3} \mathrm{COOH}$ (15: 0.5: $0.3 \mathrm{ml}$ ) as developing solvents. The developed chromatograms were visualized by spraying with vanillin $/ \mathrm{H}_{2} \mathrm{SO}_{4}$, followed by heating with a heating gun until maximum development of the spots color. On the basis of screening experiments, two metabolites were reproducibly formed by Rhizopus oryzae (RCMB 014002), and one metabolite formed by Aspergillus niger (RCMB002007(5)001002(2) after $72 \mathrm{~h}$.

\section{Preparative Biotransformation of 2,5dihydroxycinnamic acid (1):}

Preparative scale transformation of 2,5 dihydroxycinnamic acid Rhizopus oryzae (RCMB 014002) and Aspergillus niger (RCMB002007(5)001002(2) cultures which gave the best results in screening were incubated separately as before in fifty, $125 \mathrm{~mL}$ stainless steelcapped Delong culture flasks, each containing $25 \mathrm{~mL}$ of medium,2,5 dihydroxycinnamic acid(1) (1.5g, with Rhizopus oryzae) and (1g, with Aspergillus niger), were dissolved separately in $10 \mathrm{mLDMF}$, and evenly distributed among the $24 \mathrm{~h}$-old stage-II cultures. After $72 \mathrm{~h}$, the contents of 50 flasks were combined and centrifuged at $10,000 \times \mathrm{g}$ at $4{ }^{\circ} \mathrm{C}$ for 20 min. The supernatant was extracted with three $500 \mathrm{~mL}$ volumes of EtOAc; n-BuOH (9:1 $\mathrm{V} / \mathrm{V}$ ). The organic layer was pooled, dried over anhydrous $\mathrm{Na}_{2} \mathrm{SO}_{4}$, filtered through sintered glass, and vacuum-concentrated to yield $500 \mathrm{mg}$ and $340 \mathrm{mg}$ of (1) with Rhizopus oryzae and Aspergillus niger, respectively, as viscous brown residues.

\section{Isolation and Purification of the Metabolites}

The resulting brown residue from fermentation of 2,5-dihydroxy cinnamic acid (1) with Rhizopus oryzae (500 mg) was chromatographed over a silica gel TLC first column (1.5 x $100 \mathrm{~cm}, 100 \mathrm{~g})$ using $n$-hexane gradually enriched with EtOAc (100:0 $\rightarrow 0: 100)$. Three fractions; A $(75 \mathrm{mg}), \mathrm{B}(36 \mathrm{mg})$ and $\mathrm{C}(55 \mathrm{mg})$ were obtained based on TLC analysis; $\mathrm{CH}_{2} \mathrm{Cl}_{2}: \mathrm{MeOH}: \mathrm{CH}_{3} \mathrm{COOH}(15: 0.5: 0.3 \mathrm{ml})$ as developing solvents. Fractions A and B were separately re-chromatographed over silica gel column using $n$-hexane: EtOAcgradient solvent system (80:20 $\rightarrow$ 50:50). Final sample purifications were carried out with Sephadex LH-20 columns eluted with $\mathrm{CH}_{2} \mathrm{Cl}_{2}$ : $\mathrm{MeOH}$ (70:30) or (60:40) to afford 2,5-dihydroxy cinnamic acid metabolites Cin-RM-1 (18 mg) and Cin-RM-2 (27 mg).

The EtOAc extract from scaling up the reaction of (1) with Aspergillus niger (340 $\mathrm{mg})$ was chromatographed on a silica gel column $(1.5 \times 100 \mathrm{~cm}, 100 \mathrm{~g})$ eluted with mixtures of $\mathrm{CH}_{2} \mathrm{Cl}_{2}$ and $\mathrm{MeOH}$. Fractions eluted with $3 \% \mathrm{MeOH}$ in $\mathrm{CH}_{2} \mathrm{Cl}_{2}(52 \mathrm{mg})$ contained one major spot $\left(\mathrm{R}_{\mathrm{f}}\right.$ 0.55, $\mathrm{CH}_{2} \mathrm{Cl}_{2}$ : $\mathrm{MeOH}$ : Acetic acid (15: 0.5: $\left.0.3 \mathrm{ml}\right)$ and several minors which are more polar. Re-chromatography on silica gel column using the same solvent system afforded metabolite Cin-AM-3 (16 mg).

Metabolite [Cin-RM-1]:Was obtained as a colorless oily product. It gave a bluish green color with vanillin/sulfuric acid. The molecular formula was determined to be $\mathrm{C}_{9} \mathrm{H}_{10} \mathrm{O}_{3}$ by EI-MS m/z (rel. int.): $166(\mathrm{M})^{+}, 150(\mathrm{M}-\mathrm{OH})^{+}, 137\left(\mathrm{M}-\mathrm{CH}_{2} \mathrm{OH}+\mathrm{H}\right)^{+}, 122(\mathrm{M}-44$ $\left[\mathrm{C}_{2} \mathrm{H}_{4} \mathrm{O} \text { from side chain }\right)^{+}, 109\left(\mathrm{M}-58\left[\mathrm{C}_{3} \mathrm{H}_{6} \mathrm{O} \text {, prop-2-en-1-ol] }+\mathrm{H}\right)^{+}\right.$; UV $\lambda_{\max }(\mathrm{MeOH}): 267$ and $292 \mathrm{~nm}, \mathrm{IR}(\mathrm{KBr}) \mathrm{cm}^{-1}: 3350(-\mathrm{OH}), 3030(=\mathrm{C}-\mathrm{H}), 1515,1590$ (aromatic C=C), 2870 $(\mathrm{CH}), 2980,1550(\mathrm{C}=\mathrm{C}), 1430,1390,1100(\mathrm{C}-\mathrm{O}) ;{ }^{1} \mathrm{H}-\mathrm{NMR}\left(500 \mathrm{MHz}, \mathrm{CD}_{3} \mathrm{OD}\right): \delta_{\mathrm{H}} 6.85(1 \mathrm{H}$, $\mathrm{d}, J=8.5 \mathrm{~Hz}, \mathrm{H}-3), 7.21(1 \mathrm{H}, \mathrm{d}, J=2.5 \mathrm{~Hz}, \mathrm{H}-4), 7.60(1 \mathrm{H}, \mathrm{dd}, J=8.5,2.5 \mathrm{~Hz}, \mathrm{H}-6), 6.83(1 \mathrm{H}$, d, $J=16.2 \mathrm{~Hz}, \mathrm{H}-7), 6.78(1 \mathrm{H}, \mathrm{ddd}, J=16.2,7.8,6.7 \mathrm{~Hz}, \mathrm{H}-8), 4.25(1 \mathrm{H}, \mathrm{dd}, J=11.5,6.7 \mathrm{~Hz}$, H-9a),3.75 (1H, dd, $J=11.5,6.7 \mathrm{~Hz}, \mathrm{H}-9 \mathrm{~b})$.

Metabolite [Cin-RM-2]:Was obtained as a colorless amorphous solid. It gave a blue color with vanillin/sulfuric acid.The molecular formula was determined to be $\mathrm{C}_{11} \mathrm{H}_{14} \mathrm{O}_{4}$ by EI-MS $m / z$ (rel. int.): $210(\mathrm{M})^{+}, 195(\mathrm{M}-\mathrm{OH}+\mathrm{H})^{+}, 175\left(\mathrm{M}-2 \mathrm{H}_{2} \mathrm{O}+\mathrm{H}\right)^{+}, 151(\mathrm{M}-58$ $\left[\mathrm{C}_{3} \mathrm{H}_{6} \mathrm{O}\right.$, prop-2-en-1-ol, side chain $\left.]-\mathrm{H}\right)^{+}, 122\left(\mathrm{M}-58\left[\mathrm{C}_{3} \mathrm{H}_{6} \mathrm{O}\right.\right.$, prop-2-en-1-ol, side chain $]$ $\left.\mathrm{OCH}_{3}+\mathrm{H}\right)^{+}, 110\left(\mathrm{M}-2 \mathrm{OCH}_{3}-2 \mathrm{H}_{2} \mathrm{O}\right)^{+}$; UV $\lambda_{\max }(\mathrm{MeOH}): 265$ and $298 \mathrm{~nm}, \mathrm{IR}(\mathrm{KBr}) \mathrm{cm}^{-1}$ : 
$3330(-\mathrm{OH}), 3020(=\mathrm{C}-\mathrm{H}), \quad 1595($ aromatic $\mathrm{C}=\mathrm{C}), 2875(\mathrm{CH}), 2980,1560(\mathrm{C}=\mathrm{C}), 2820$ $\left(\mathrm{OCH}_{3}\right), 1410,1100(\mathrm{C}-\mathrm{O}) ;{ }^{1} \mathrm{H}$ NMR $\left(500 \mathrm{MHz}, \mathrm{CD}_{3} \mathrm{OD}\right): \delta_{\mathrm{H}} 6.74(1 \mathrm{H}, \mathrm{s}, \mathrm{H}-3), 6.98(1 \mathrm{H}, \mathrm{s}, \mathrm{H}-$ 6), $6.32(1 \mathrm{H}, \mathrm{d}, J=16.5 \mathrm{~Hz}, \mathrm{H}-7), 6.83(1 \mathrm{H}, \mathrm{ddd}, J=16.5,7.8,5.8 \mathrm{~Hz}, \mathrm{H}-8), 4.19(1 \mathrm{H}, \mathrm{dd}, J$ $=14.2,4.7 \mathrm{~Hz}, \mathrm{H}-9 \mathrm{a}), 3.70(1 \mathrm{H}, \mathrm{dd}, J=14.2,4.7 \mathrm{~Hz}, \mathrm{H}-9 \mathrm{~b}), 3.77\left(3 \mathrm{H}, \mathrm{s}, 4-\mathrm{OCH}_{3}\right), 3.73(3 \mathrm{H}$, $\left.\mathrm{s}, 5-\mathrm{OCH}_{3}\right)$.

Metabolite [Cin-AM-3]:Was obtained as a pale yellow amorphous powder. It gave a blue color with vanillin/sulfuric acid.The molecular formula was determined to be $\mathrm{C}_{10} \mathrm{H}_{10} \mathrm{O}_{4}$ by EI-MS m/z (rel. int.): $194(\mathrm{M})^{+}, 177\left(\mathrm{M}-\mathrm{H}_{2} \mathrm{O}+\mathrm{H}\right)^{+}, 163\left(\mathrm{M}-\mathrm{OCH}_{3}+\mathrm{H}\right)^{+}, 148\left(\mathrm{M}-\mathrm{OCH}_{3}\right.$ - $\mathrm{OH})^{+}, 134(\mathrm{M}-\text { Carboxylic acid - OH})^{+}, 121\left(\mathrm{M}-~^{-} \mathrm{OCH}_{3}-\text { Carboxylic acid }+\mathrm{H}\right)^{+}, 107(\mathrm{M}-$ $\mathrm{OCH}_{3}-\mathrm{OH}-$ Carboxylic acid) ${ }^{+}$, UV $\lambda_{\max }(\mathrm{MeOH}): 325,290 \mathrm{sh}, 245 \mathrm{sh}, 218 \mathrm{~nm}$, IR (KBr) cm-1: 3450 (carboxylic acid O-H stretching), 1690 (carboxylic acid $\mathrm{C}=\mathrm{O}$ stretching), 1275 cm-1 (carboxylic acid C-O stretching) 1510; 1605 (aromatic C=C) $2875(\mathrm{CH}), 2820\left(\mathrm{OCH}_{3}\right)$; ${ }^{1} \mathrm{H}-\mathrm{NMR}\left(500 \mathrm{MHz}, \mathrm{CD}_{3} \mathrm{OD}\right): \delta_{\mathrm{H}} 6.85(1 \mathrm{H}, \mathrm{d}, J=9.0 \mathrm{~Hz}, \mathrm{H}-3), 6.85(1 \mathrm{H}, \mathrm{d}, J=9.0 \mathrm{~Hz}, \mathrm{H}-4)$, $6.97(1 \mathrm{H}, \mathrm{dd}, J=2.8,9.0 \mathrm{~Hz}, \mathrm{H}-6), 7.92(1 \mathrm{H}, \mathrm{d}, J=16.2 \mathrm{~Hz}, \mathrm{H}-7), 6.41(1 \mathrm{H}, \mathrm{d}, J=16.2 \mathrm{~Hz}$, $\mathrm{H}-8), 3.85\left(3 \mathrm{H}, \mathrm{s}, 5-\mathrm{OCH}_{3}\right) ;{ }^{13} \mathrm{C}$ NMR $\left(100 \mathrm{MHz}, \mathrm{CD}_{3} \mathrm{OD}\right): \delta_{\mathrm{C}} 123.56(\mathrm{C}-1), 150.95(\mathrm{C}-2)$, 117.98 (C-3), 113.72 (C-4), 152.09 (C-5), 112.60 (C-6), 140.07 (C-7), 118.29 (C-8), 56.50 $\left(\mathrm{OCH}^{3}-5\right)$.

\section{In-Vitro Biological Evaluation:}

Antioxidant activity: The antioxidant activity of 2,5dihydroxycinnamic acid (1) and its metabolites[Cin-M-1-M-3], were analyzed using two different techniques; DPPH radical scavenging activity and $\mathrm{FeSO}_{4} / \mathrm{H}_{2} \mathrm{O}_{2}$-stimulated lipid peroxidation in rat tissue homogenate.

Chemicals: 1,1-Diphenyl-2-picrylhydrazyl (DPPH), butylatedhydroxytoluene (BHT), 2thiobarbituric acid, ferrous sulphate, hydrogen peroxide, were purchased from Sigma Chemical Company (St. louis, Mo, USA).

Animals: Male Westar rats (250-300 g) were handled according to international regulations. They were allowed to take standard laboratory diet and water ad libitum, and the animals were maintained at $24{ }^{\circ} \mathrm{C}$ with $12 \mathrm{~h}$ light period.

\section{A. DPPH radical scavenging activity}

The ability of the extracts to scavenge free radicals was determined according to the method of De La Torre Boronat and Lopez Tamames (1997). In a 96-well plate, $10 \mu \mathrm{L}$ of each sample or standard dissolved in ethanol $(100 \mu \mathrm{g} / \mathrm{mL})$ was added to $190 \mu \mathrm{L}$ of 316 $\mu \mathrm{M} / \mathrm{mL}$ DPPH solution. A blank was prepared using ethanol. After incubation at $30{ }^{\circ} \mathrm{C}$ for 30 min, the absorbance of each solution was measured at $517 \mathrm{~nm}$. DL- $\alpha$-tocopherol and BHT were used as positive controls. The scavenging activity of the samples was calculated as a percentage of free radical inhibition according to the formula:

$$
\% \text { inhibition }=\frac{A_{\text {blank }}-A_{\text {sample }}}{A_{\text {blank }}} \times 100
$$

Where ${ }^{\mathbf{A}}$ blank is the absorbance of the blank at zero time and ${ }^{\mathbf{A}}$ sample is the absorbance of the sample after $30 \mathrm{~min}$. All experiments were carried out in triplicate.

\section{B. $\mathrm{FeSO}_{4} / \mathrm{H}_{2} \mathrm{O}_{2}$-stimulated lipid peroxidation in rat tissue homogenate (Cesar et al., 1988; Taha et al., 2011).}

Male Westar rats (250-300 g) were sacrificed, and the rat tissues (brain, heart and liver: $0.3-0.5 \mathrm{~g}$ ) were rapidly removed and homogenized in 10 volumes of $15 \mathrm{mM}$ Krebs buffer. Homogenates were centrifuged at $3000 \mathrm{x}$ for 10 minutes at $4{ }^{\circ} \mathrm{C}$ to give supernatants 
containing $(1.2 \mathrm{mg}$ of protein/ $\mathrm{ml}$; brain $),(1.7 \mathrm{mg}$ of protein/ $\mathrm{ml}$; heart $)$ and $(2.5 \mathrm{mg}$ of protein/ $\mathrm{ml}$; liver) using Coomassie plus protein assay reagent and albumin standard as determined by the Bradford method (1976). During aerobic incubation of the tissue homogenates, MDA released reacts with thiobarbituric acid (TBA) to give a pink color. The capability of the samples to inhibit MDA formation is used as a measure of their antioxidant activity. The pink color complex of thiobarbituric acid reacting substance (TBARS) is measured at $532 \mathrm{~nm}$ for the test samples and positive standards (DL- $\alpha$ - tocopherol and BHT) $(200 \mu \mathrm{g} / \mathrm{mL})$, as well as, 2,5dihydroxycinnamic acid (1) and their metabolites (Cin-M-1-M-3, $100 \mu \mathrm{g} / \mathrm{mL}$ ). The results were expressed as nano-moles of MDA equivalents per milligram of protein of rat (brain, heart and liver) homogenates. All measurements were done in triplicate. The capability to inhibit MDA formation was calculated using the following equation:

$$
\text { Inhibition effects }(\%)=1-\frac{\text { MDA in tissue homogenate with test extracts }}{\text { MDA in tissue homogenate without test extracts }} \times 100
$$

\section{Statistical Analysis}

All data were expressed as mean \pm SE. Student's t-test [33] was applied for detecting the significance of difference between each sample; $\mathrm{P}<0.05$ was taken as the level of significance.

\section{RESULTS AND DISCUSSION}

\section{A- Structure Elucidation of isolated metabolites}

Of 11 microorganisms screened for their abilities to catalyze the bioconversion of 2,5dihydroxy cinnamic acid (1), Rhizopus oryzae (RCMB 014002) and Aspergillus niger (RCMB002007 (5)001002(2) reproducibly formed after $72 \mathrm{~h}$ of incubation two major metabolites [Cin-RM-1 and Cin-RM-2] from Rhizopus oryzae and [Cin-AM-3] from Aspergillus niger in good yield. None of the observed metabolites were formed in control cultures or in media containing no microorganisms but incubated under the same conditions. Following solvent extraction and column chromatographic purification, samples of metabolites were subjected to spectral analysis. Spectra (UV, IR, NMR, and mass spectrometry) for isolated metabolites were established by comparing their spectral data to those given in the literature.

Metabolite (Cin-RM-1): was obtained as a colorless oily product. It gave a bluish green color with vanillin/sulfuric acid. The UV spectrum recorded in $\mathrm{MeOH}$ showed absorption maxima attributable to a conjugated aromatic ring at $\lambda_{\max } 267$ and $292 \mathrm{~nm}$. The IR spectrum showed characteristic bands accounting for a phenolic group at $3350 \mathrm{~cm}^{-1}(-\mathrm{OH}), 3030 \mathrm{~cm}^{-1}$ $(=\mathrm{C}-\mathrm{H}), 1515,1590 \mathrm{~cm}^{-1}$ (aromatic $\left.\mathrm{C}=\mathrm{C}\right), 2870 \mathrm{~cm}^{-1}(\mathrm{CH}), 2980,1550 \mathrm{~cm}^{-1}(\mathrm{C}=\mathrm{C}), 1430,1390$, $1100 \mathrm{~cm}^{-1}$ (C-O). Addetionally, in IR spectrum, peak at $1680 \mathrm{~cm}^{-1}(\mathrm{C}=\mathrm{O})$ in (1) was disappeared and a broad peak appeared at $3350 \mathrm{~cm}^{-1}(\mathrm{OH})$. The empirical formula was determined by accurate mass measurement as $\mathrm{C}_{9} \mathrm{H}_{10} \mathrm{O}_{3}$ based on the molecular ion base peak $\mathrm{atm} / \mathrm{z} 166(\mathrm{M})^{+}$with 14 mass unit lower than of parent molecule (substrate, 180 mass unit), It also showed fragment ions at m/z $150(\mathrm{M}-\mathrm{OH})^{+}, 137\left(\mathrm{M}-\mathrm{CH}_{2} \mathrm{OH}+\mathrm{H}\right)^{+}, 122\left(\mathrm{M}-44\left[\mathrm{C}_{2} \mathrm{H}_{4} \mathrm{O}\right.\right.$ from side chain $)^{+}$and $109\left(\mathrm{M}-58\left[\mathrm{C}_{3} \mathrm{H}_{6} \mathrm{O} \text {, prop-2-en-1-ol }\right]+\mathrm{H}\right)^{+}$by EI-MS.

The ${ }^{1} \mathrm{H}-\mathrm{NMR}$ spectrum of metabolite (Cin-RM-1) displayed a typical signals of resonances that was associated with a 2,5-disubstituted $(E)$-cinnamyl alcoholunit; three aromatic proton signals as an $\mathrm{ABX}$ spin-system at $\delta_{\mathrm{H}} 6.85(1 \mathrm{H}, \mathrm{d}, J=8.5 \mathrm{~Hz}, \mathrm{H}-3), 7.21(1 \mathrm{H}$, 
$\mathrm{d}, J=2.5 \mathrm{~Hz}, \mathrm{H}-4), 7.60(1 \mathrm{H}, \mathrm{dd}, J=8.5,2.5 \mathrm{~Hz}, \mathrm{H}-6)$, indicating the presence of a trisubstituted aromatic ring in the molecule. Two olefinic protons as an $\mathrm{AB}$ spin-system at $\delta_{\mathrm{H}} 6.83(1 \mathrm{H}, \mathrm{d}, J=16.2 \mathrm{~Hz}, \mathrm{H}-7)$ and $6.78(1 \mathrm{H}, \mathrm{ddd}, J=16.2,7.8,6.7 \mathrm{~Hz}, \mathrm{H}-8)$, coupling constant $16.2 \mathrm{~Hz}$ between olefinic protons $\mathrm{H}-7$ and $\mathrm{H}-8$ suggests clearly them being intrans geometry to each other's. Additionally, signals for a methylene group bearing a secondary hydroxyl as doublet of doublet at $\delta_{\mathrm{H}} 4.25(1 \mathrm{H}, \mathrm{dd}, J=11.5,6.7 \mathrm{~Hz}, \mathrm{H} 9 \mathrm{a})$ and $3.75(1 \mathrm{H}, \mathrm{dd}, J$ $=11.5,6.7 \mathrm{~Hz}, \mathrm{H} 9 \mathrm{~b}$ ) were also observed. On the basis of these spectral data it was suggested that the carbonyl group of 2,5-dihydroxy cinnamic acid (substrate) was reduced to alcohol functional group. Therefore, the structure of metabolite [Cin-RM-1] was identified as 2,5dihydroxy cinnamoyl alcohol.

Metabolites (Cin-RM-2): was obtained as a colorless amorphous solid. It gave a blue color with vanillin/sulfuric acid. The UV spectrum recorded in $\mathrm{MeOH}$ showed absorption maxima attributable to a conjugated aromatic ring at $\lambda_{\max } 265$ and $298 \mathrm{~nm}$. The IRspectrum displayed characteristic absorption bands at $3330 \mathrm{~cm}^{-1}$ for hydroxyl group. The absorption band near $1595,1504,1465 \mathrm{~cm}^{-1}$ is for aromatic $\mathrm{C}=\mathrm{C}$ stretching vibration and the band at $2875 \mathrm{~cm}^{-1}$ is for $\mathrm{C}-\mathrm{H}$ bending vibration of aromatic compound. The absorption band at $2980,1560 \mathrm{~cm}^{-1}$ for $-\mathrm{C}=\mathrm{C}$ - stretching. The bands at 2820 and $1176-1323 \mathrm{~cm}^{-1}$ showed presence of methoxy group (-C-O stretching frequency) in the molecule. The empirical formula was determined by accurate mass measurement as $\mathrm{C}_{11} \mathrm{H}_{14} \mathrm{O}_{4}$ based on the molecular ion base peak atm/z 210 $(\mathrm{M})^{+}$with 30 mass unit over that of substrate (180 mass unit) and 44 mass unit over that of metabolite (Cin-RM-1) (166 mass unit). It also showed fragment ion peaks at m/z 195 (M$\mathrm{OH}+\mathrm{H})^{+}, 175\left(\mathrm{M}-2 \mathrm{H}_{2} \mathrm{O}+\mathrm{H}\right)^{+}, 151\left(\mathrm{M}-58\left[\mathrm{C}_{3} \mathrm{H}_{6} \mathrm{O} \text {, prop-2-en-1-ol, side chain }\right]-\mathrm{H}\right)^{+}, 122$ (M- $58\left[\mathrm{C}_{3} \mathrm{H}_{6} \mathrm{O}\right.$, prop-2-en-1-ol, side chain $\left.]-\mathrm{OCH}_{3}+\mathrm{H}\right)^{+}, 110\left(\mathrm{M}-2 \mathrm{OCH}_{3}-2 \mathrm{H}_{2} \mathrm{O}\right)^{+}$, by EIMS.

The ${ }^{1} \mathrm{H}-\mathrm{NMR}$ spectrum of [Metabolite-RM-2], displayed two meta-coupled singlets each for $1 \mathrm{H}$, at $\delta_{\mathrm{H}} 6.74(\mathrm{H}-3)$ and $\delta_{\mathrm{H}} 6.98(\mathrm{H} 6)$ in the aromatic region indicating the presence of a tetra-substituted aromatic ring in the molecule. It also displayed a typical signals of resonances at $\delta_{\mathrm{H}} 6.32(1 \mathrm{H}, \mathrm{d}, J=16.5 \mathrm{~Hz}, \mathrm{H}-7), 6.83(1 \mathrm{H}, \mathrm{ddd}, J=16.5,7.8,5.8 \mathrm{~Hz}, \mathrm{H}-8), 4.19$ $(1 \mathrm{H}, \mathrm{dd}, J=14.2,4.7 \mathrm{~Hz}, \mathrm{H} 9 \mathrm{a})$ and $3.70(1 \mathrm{H}, \mathrm{dd}, J=14.2,4.7 \mathrm{~Hz}, \mathrm{H} 9 \mathrm{~b})$. Coupling constant $16.5 \mathrm{~Hz}$ between olefinic protons $\mathrm{H}-7$ and $\mathrm{H}-8$ suggests clearly them being intrans geometry to each other's.Additionally, two sharp proton signals for two $\mathrm{OCH}_{3}$ groups at $\delta_{\mathrm{H}} 3.77(3 \mathrm{H}$, s, 4- $\left.\mathrm{OCH}_{3}\right)$ and 3.72(3H, s, 5- $\left.\mathrm{OCH}_{3}\right)$ were also observed.

Therefore, the structure of metabolite [Cin-RM-2] was identified as 2-Hydroxy-4,5-

\section{Dimethoxy cinnamoyl alcohol.}

Metabolite [Cin-AM-3]: was obtained as pale yellow amorphous powder. It gave a blue color with vanillin/sulfuric acid. Compound [Cin-AM-3] exhibited UV and IR absorptions confirming its phenolic nature $\left(325,290 \mathrm{sh}, 245 \mathrm{sh}, 218 \mathrm{~nm}\right.$ ), [3450 $\mathrm{cm}^{-1}$ (carboxylic acid O-H stretching), $1690 \mathrm{~cm}^{-1}$ (carboxylic acid $\mathrm{C}=\mathrm{O}$ stretching), $1275 \mathrm{~cm}-1$ (carboxylic acid $\mathrm{C}-\mathrm{O}$ stretching) $1510 ; 1605 \mathrm{~cm}^{-1}$ (aromatic $\left.\mathrm{C}=\mathrm{C}\right), 2875 \mathrm{~cm}^{-1}(\mathrm{CH})$ and $2820 \mathrm{~cm}^{-1}\left(\mathrm{OCH}_{3}\right)$.

The molecular formula was determined as $\mathrm{C}_{10} \mathrm{H}_{10} \mathrm{O}_{4}$ on the basis of the molecular ion peaks observed at m/z $194(\mathrm{M})^{+}, 177\left(\mathrm{M}-\mathrm{H}_{2} \mathrm{O}+\mathrm{H}\right)^{+}, 163\left(\mathrm{M}-\mathrm{OCH}_{3}+\mathrm{H}\right)^{+}, 148\left(\mathrm{M}-\mathrm{OCH}_{3}-\right.$ $\mathrm{OH})^{+}, 134(\mathrm{M}-\text { carboxylic acid - OH })^{+}, 121\left(\mathrm{M}-\mathrm{OCH}_{3} \text { - carboxylic acid }+\mathrm{H}\right)^{+}, 107\left(\mathrm{M}-\mathrm{OCH}_{3}\right.$ - OH -carboxylic acid) ${ }^{+}$by EI-MS. This formula was in good agreement with the ${ }^{13} \mathrm{C}-\mathrm{NMR}$ spectrum, which showed 10 signals containing five methines, one methoxyl and four quaternary carbons. The molecular ion peak atm/z $194(\mathrm{M})^{+}$with 14 mass unit over that of substrate and the ${ }^{1} \mathrm{H}$ - and ${ }^{13} \mathrm{C}-\mathrm{NMR}$ spectra of [Cin-AM-3]revealed that this metabolite had the same carbon skeleton as [substrate], the only difference [Cin-AM-3] possessed one methoxyl group versus a hydroxyl group in [substrate]. 
The ${ }^{1} \mathrm{H}$ - and ${ }^{13} \mathrm{C}-\mathrm{NMR}$ spectra of [Cin-AM-3], exhibited three aromatic proton and carbonsignals as an ABX spin-systemat $\delta_{\mathrm{H}} 6.85\left(1 \mathrm{H}, \mathrm{d}, J=9.0 \mathrm{~Hz}, \mathrm{H}-3, \delta_{\mathrm{C}} 117.98\right), 6.81(1 \mathrm{H}$, $\left.\mathrm{d}, J=2.8 \mathrm{~Hz}, \mathrm{H}-4, \delta_{\mathrm{C}} 113.72\right)$ and $6.97\left(1 \mathrm{H}, \mathrm{dd}, J=2.8,9.0 \mathrm{~Hz}, \mathrm{H}-6, \delta_{\mathrm{C}} 112.60\right)$, indicating the presence of a trisubstituted aromatic ring. Two olefinic protons and carbons as an $\mathrm{AB}$ spin-system at $\delta_{\mathrm{H}} 7.92\left(1 \mathrm{H}, \mathrm{d}, J=16.2 \mathrm{~Hz}, \mathrm{H}-7, \delta_{\mathrm{C}} 140.07\right)$ and $6.41(1 \mathrm{H}, \mathrm{d}, J=16.2 \mathrm{~Hz}, \mathrm{H}-8$, $\left.\delta_{\mathrm{C}} 118.29\right)$, the large value of coupling constant $(16.2 \mathrm{~Hz})$ indicated the presence of transdisubstituted ethylene moiety in the molecule. The downfield signal for three hydrogens at $\delta_{\mathrm{H}}$ $3.85, \delta_{\mathrm{C}} 56.50$ ) indicates that methyl group is attached to electron withdrawing oxygen atom of $\mathrm{OCH}_{3}$ group at $\mathrm{C}-5$. The ${ }^{13} \mathrm{C}$ chemical shifts of a carbon at $\delta_{\mathrm{C}} 169.78$ indicated the presence of carboxylic functional group in the molecule. The upfield chemical shifts of one of the ethyleniccarbon (C-8) and a quaternary carbon at $\delta_{\mathrm{C}} 123.56(\mathrm{C}-1)$ indicated that the carboxylic group is located at $\mathrm{C}-8$ position. The ${ }^{13} \mathrm{C}$-chemical shifts of carbon atoms at $\delta_{\mathrm{C}} 152.09$ (C-5) versus 150.39 (C-5) in2,5-dihydroxy cinnamic acid, indicated that the methoxyl group was attached at $\mathrm{C}-5$ position.

Therefore, the structure of metabolite [Cin-AM-3] was identified as 2-hydroxy-5methoxy cinnamic acid.

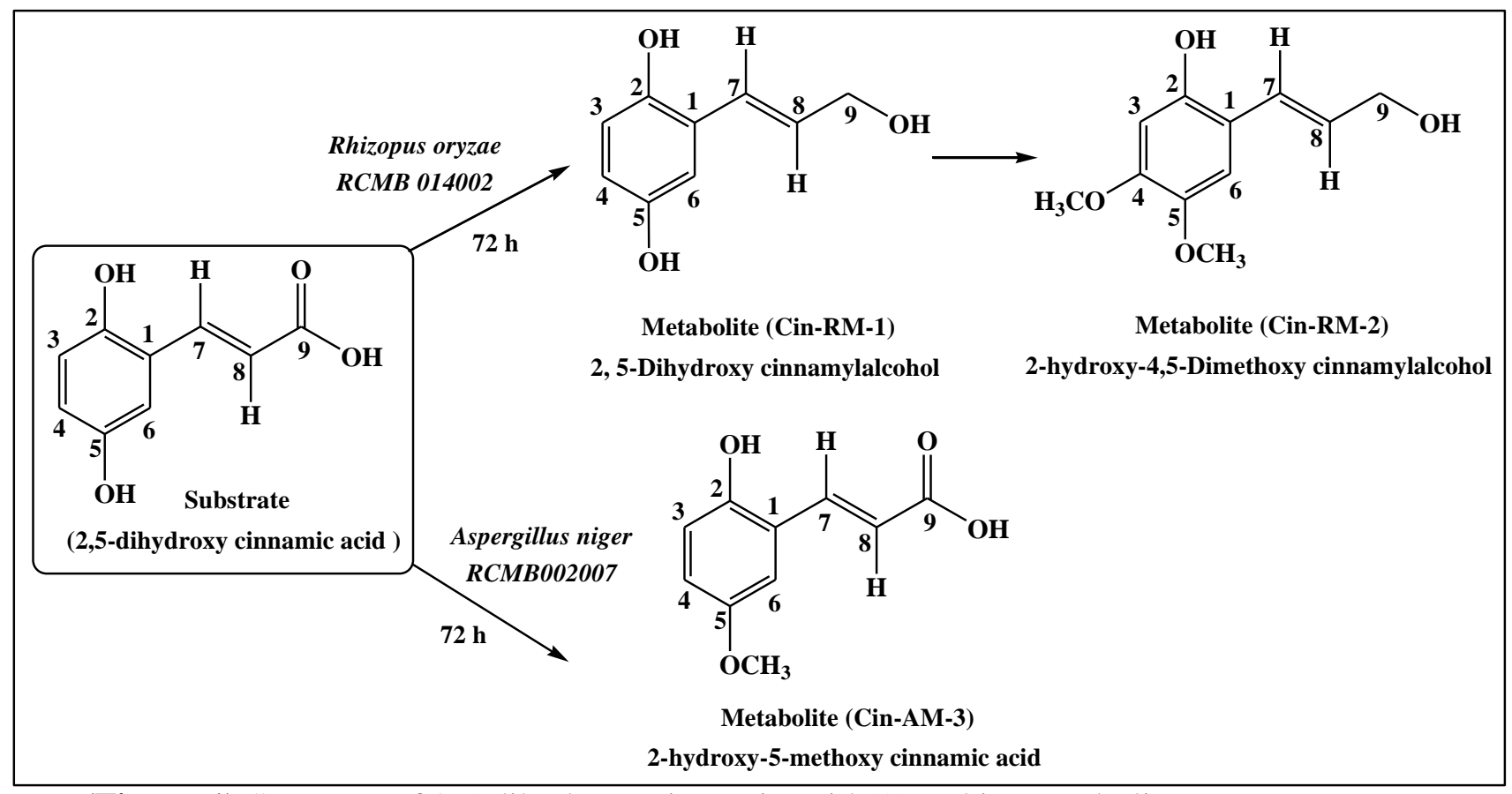

(Figure 1) Structure of 2,5-dihydroxy cinnamic acid (1) and its metabolites.

\section{CONCLUSION}

The first step of the 2,5-dihydroxycinnamic acid pathway by Rhizopus oryzae is the conversion of 2,5-dihydroxycinnamic acid to 2,5-dihydroxycinnamic acid-CoA, which is catalyzed by cinnamoyl-CoA reductase (Kato et al., 1991). The subsequent reduction by cinnamyl alcohol dehydrogenase leads to the intermediate 2,5-dihydroxycinnamaldehyde followed by 2, 5-dihydroxy cinnamyl-alcohol [Cin-RM-1], (Figure 2). The biosynthetic pathway of 2-hydroxy-4,5-dimethoxy cinnamyl-alcohol [Cin-RM-2], involves a methylation of the hydroxyl group at C-5 position of metabolite (Cin-RM-1), by cinnamoyl- $O$ methyltransferase (COMT), followed by hydroxylation of the aromatic C-4 position of the intermediate 2-hydroxy-5-methoxy cinnamylalcohol by cinnamyl-4-hydroxylase. Further 
Methylation of this hydroxyl group by $O$-methyltransferase (COMT) (Maria -Joao et al., 2007), leads to 2-hydroxy-4,5-Dimethoxy cinnamylalcohol [Cin-RM-2].

For the isolated metabolite (Cin-AM-3) by Aspergillus niger, 2,5-dihydroxycinnamic acid $O$-methyltransferase (COMT)catalyzes preferentially the methylation of the hydroxyl group at C-5 position of the substrate leads to 2-hydroxy-5-methoxy cinnamic acid (CinAM-3), (Figure 2).

\section{B- Results of Biological evaluation (Antioxidant Activities)}

\section{B.1- Assay for DPPH free radical scavenging activity}

2,2-Diphenyl-1-picryl hydrazyl (DPPH) is a stable free radical and accepts an electron or hydrogen radical to become a stable diamagnetic molecule (Kuo et al. (1999)). The DPPH radical is considered to be a model of a lipophilic radical. A chain reaction in lipophilic radicals was initiated by the lipid autoxidation. The purpose of this study was to evaluate the antioxidant activites of the substrate; 2,5-dihydroxy cinnamic acid and their isolated metabolites obtained by Rhizopus oryzae and Aspergillus niger cultures fungi as new potential sources of natural antioxidants. Well known antioxidant D, L- $\alpha$-tocopherol and butylated-hydroxyl toluene(BHT) were used for comparison. The scavenging effects of substrate, metabolites and positive controls D, L, $\alpha$-tocopherol and BHT on DPPH radical are compared and shown in (Table 1). It was observed that 2,5-dihydroxycinnamic acid showed DPPH quenching with $\mathrm{IC}_{50}$ values at 51.3\%. Metabolite; Cin-RM-2 (2-hydroxy-4,5Dimethoxy cinnamylalcohol), showed the highest activity in DPPHradica quenching (63.4\%), than those of such typical antioxidants D, L, $\alpha$-tocopherol $(62.8 \%)$ and BHT $(50.2 \%)$ respectively. Cin-AM-3(2-hydroxy-5-methoxy cinnamic acid) [54.2\%], Cin-RM-1 (2, 5Dihydroxy cinnamylalcohol) [53.5\%], showed slightly less DPPH radical quenching than $\mathrm{D}, \mathrm{L}, \alpha$-tocopherol but its more than BHT.

In conclusion, the results obtained with isolated metabolites have indicated that scavenging effects is dependent on their chemical structure and thought to be due to their hydrogen donating activity. In general phenolic $\mathrm{OH}$ is known as scavenger of free radicals and it consequently exhibits antioxidative activity (Hosny, and Rosazza, 2002). Especially, in regards to substitution on the phenyl ring several studies have reported that the existence of an electron donating group such as methoxyl substitution as with several metabolites obtained in this study enhances antioxidant effectiveness (Hosny, and Rosazza, 2002), claimed that the phenolic group is essential for the free-radical-scavenging activity and that the presence of the methoxy group further increased the activity.

Table (1) Effects of substrates, metabolites and positive controls on the in vitro Free Radical Generation.

\begin{tabular}{|c|c|}
\hline Bioassay & DPPH \% decoloration \\
\hline \multicolumn{2}{|c|}{ Substrate } \\
\hline 2,5-dihydroxy-cinnamic acid & $51.3 \pm 1.30$ \\
\hline
\end{tabular}




\begin{tabular}{|c|c|}
\hline \multicolumn{2}{|c|}{ Metabolite } \\
\hline Cin-RM-1 & $53.5 \pm 1.40$ \\
\hline Cin-RM-2 & $63.4 \pm 1.50$ \\
\hline Cin-AM-3 & $54.2 \pm 1.40$ \\
\hline \multicolumn{2}{|c|}{ Positive control } \\
\hline D,L, $\alpha$-tocopherol & $62.8 \pm 1.50$ \\
\hline BHT & $50.2 \pm 1.30$ \\
\hline
\end{tabular}

Values are presented as mean $\pm \mathrm{SE}$ of 3 -test sample observation. $P<0.05$ for all values.

\section{B.2- Ferrous sulphate-H2O2-stimulated lipid peroxidation in rat tissue homogenate.}

Lipid peroxidation is a free radical mediated process which has been implicated in a variety of disease states. It involves the formation and propagation of lipid radicals, uptake of oxygen, a re-arrangement of the double and unsaturated lipids that results in a variety of degraded products (e.g., alkenes, malondialdehyde (MDA), lipid hydroperoxides and conjugated dienes) that eventually causes destruction of membrane lipids. Thus lipid peroxidation and conjugated diene measurement plays important role along with MDA assay (Halliwell and Chirico, 1993). The increased peroxidation can result in changes in cellular metabolism of the hepatic and extra-hepatic tissues. Increase in accumulation of MDA, conjugated diene and hydro-peroxides in cells can result in cellular dehydration and whole cell deformity and death (Halliwell and Chirico, 1993). Itis well known that defense mechanism in liver, kidney, heart, brain and lungs are prone to oxidative damage. Alteration of fatty acid composition by increased lipid levels may contribute for lowering the resistance of tissues and higher rate of oxidative stress.

\section{B.2- Ferrous sulphate-H2O2-stimulated lipid peroxidation in rat tissue homogenate.}

There is good evidence that superoxidedismutase (SOD) and catalase are enzymes that scavenge free radicals during lipid peroxidation. The free radical chain reaction is widely accepted as a common mechanism of lipid peroxidation. Radical scavengers may directly react with and quench peroxide radicals to terminate the peroxidation chain reaction and improve the quality and stability of food products (Halliwell and Chirico, 1993).

For rat tissue homogenate (brain, heart and liver), the unstimulated control experiments the amount of thiobarbituric reactive substance (TBARS) [MDA levels without $\left.\mathrm{FeSO}_{4}-\mathrm{H}_{2} \mathrm{O}_{2}\right]$ formed in rat tissue homogenate (brain, heart and liver) were $(0.36 \pm 0.15$ $\mathrm{nmol}, \mathrm{MDA} / \mathrm{mg}$ protein $),(0.22 \pm 0.10 \mathrm{nmol}, \mathrm{MDA} / \mathrm{mg}$ protein $)$ and $(0.16 \pm 0.05 \mathrm{nmol}$, $\mathrm{MDA} / \mathrm{mg}$ protein), respectively. After induction with $200 \mu \mathrm{m} \mathrm{Fe} \mathrm{F}^{2+}-\mathrm{H}_{2} \mathrm{O}_{2}$, The amount of TBARS increased to $(0.72 \pm 1.30 \mathrm{nmol}, \mathrm{MDA} / \mathrm{mg}$ protein $), 0.65 \pm 1.25 \mathrm{nmol}, \mathrm{MDA} / \mathrm{mg}$ protein) and $(0.44 \pm 1.15 \mathrm{nmol}, \mathrm{MDA} / \mathrm{mg}$ protein) of brain, heart and liver, respectively (Table 2). 
A control experiment indicated that substrates and isolated fungal metabolites did not effect the measurement of TBARS because the absorbance at $532 \mathrm{~nm}$ was not effected by adding different substrates and isolated fungal metabolites to the rat tissue homogenate that already have been oxidatively modified because omission of rat homogenate from the reaction mixture abolished chromogen formation. D, L- $\alpha$-tochopherol and BHT also inhibited this $\mathrm{Fe}^{2+}$-induced lipid peroxidation with $\mathrm{IC}_{50}$ values in the range of $(28.23-$ $35.10 \%),(22.05-38.70 \%)$ and $(33.15-46.18 \%)$ in heart, brain and liver rat tissue homogenates, respectively. However, as shown in (Table 2), adding 200-500 $\mu \mathrm{g} / \mathrm{mL}$ of substrateson rat tissue homogenates (brain, heart and liver), reduce MDA formation in the presence of $\mathrm{Fe}^{2+}-\mathrm{H}_{2} \mathrm{O}_{2}$ with $\mathrm{IC}_{50}$ values $(22.10 \%, 10.20 \%$ and $32.25 \%)$ in heart, brain and liver rat tissue homogenatesrespectively, indicating lower anti-lipid peroxidation activities of substrates. The results obtained with the fungal metabolites; Cin-RM-1, Cin-RM-2 and Cin-AM-3 showedlow radical quenching for all tissue homogenate than those of such typical antioxidants D, L, $\alpha$-tocopherolbut its more than BHT (Table 2).

Our results clearly showed that lipid peroxidation in rat tissue homogenates (brain, heart and liver) induced by ferrous ion $/ \mathrm{H}_{2} \mathrm{O}_{2}$ as measured by MDA formation, was slightly inhibited by substrate and their metabolites. Since D,L, $\alpha$-tocopherol is thought to be associated with lipid-rich membranes, it is anti-oxidative is highly effective in protecting membranes against lipid peroxidation, as peroxyl and alkoxyl radicals. The data obtained from the present study indicates that the isolated metabolites hasanti-lipid peroxidative character with similar reaction mechanisms to those of D,L, $\alpha$-tocopherol and BHT for rat liver tissue homogenates.

Table (2) Inhibition Effect of substrates, metabolites and positive controls on $\mathrm{FeSO}_{4}-\mathrm{H}_{2} \mathrm{O}_{2}$ Induced Lipid Peroxidation (MDA production)in Rat Tissue Homogenate.

\begin{tabular}{|c|c|c|c|}
\hline \multirow{2}{*}{ Bioassay } & \multicolumn{3}{|c|}{ Inhibition effect $(\%)^{*}$} \\
\hline & Brain & Heart & Liver \\
\hline $\begin{array}{l}\text { Normal control without } \\
\mathrm{FeSO}_{4}-\mathrm{H}_{2} \mathrm{O}_{2}(\mathrm{MDA} \text { level) }\end{array}$ & $0.36 \pm 0.15$ & $0.22 \pm 0.10$ & $0.16 \pm 0.05$ \\
\hline $\begin{array}{c}\text { Induction by } \mathrm{FeSO}_{4}-\mathrm{H}_{2} \mathrm{O}_{2} \\
\text { (MDA level) }\end{array}$ & $0.72 \pm 1.30$ & $0.65 \pm 1.25$ & $0.44 \pm 1.15$ \\
\hline \multicolumn{4}{|c|}{ Substrates } \\
\hline 2,5-dihydroxy-cinnamicacid & $22.10 \pm 1.15$ & $10.20 \pm 0.08$ & $32.25 \pm 1.20$ \\
\hline \multicolumn{4}{|c|}{ Metabolites } \\
\hline Cin-RM-1 & $19.75 \pm 1.15$ & $21.40 \pm 1.15$ & $30.50 \pm 1.20$ \\
\hline Cin-RM-2 & $27.55 \pm 1.20$ & $16.95 \pm 1.15$ & $42.50 \pm 1.40$ \\
\hline Cin-AM-3 & $29.15 \pm 1.25$ & $14.70 \pm 1.10$ & $44.28 \pm 1.40$ \\
\hline \multicolumn{4}{|c|}{ Positive controls } \\
\hline D,L, $\alpha$-tocopherol & $35.10 \pm 1.30$ & $38.70 \pm 1.30$ & $46.18 \pm 1.50$ \\
\hline BHT & $28.23 \pm 1.25$ & $22.05 \pm 1.20$ & $33.15 \pm 1.30$ \\
\hline
\end{tabular}

$*$ Values are presented as mean \pm SE of 3-test sample observation. $P<0.05$ for all values. 


\section{REFERENCES}

Bradford, M. M., (1976): "Protein determination method that involves the binding of Coomassie Brilliant Blue G-250 dye to proteins"Anal. Biochem. 72: 248-254.

Cesar G. F., Brian, E. L., and Tappe, S., (1988): "Lipid peroxidation measured as thiobarbituric acid-reactive substances in tissue slices: characterization and comparison with homogenates and microsomes". Free Radical Biology and Medicine, 4 (3), 155-161.

De La Torre Boronat, M. C., and Lopez Tamames, E., (1997): "El Papel de Los Antioxidants", Alimentaria, 6, 19-27.

Fernández-Martínez, E., Bobadilla, R. A., Morales-Ríos, M. S., Muriel, P., Pérez-Alvarez, V. M. (2007): "Trans-3-phenyl-2-propenoic acid (cinnamic acid) derivatives: structure-activity relationship as hepatoprotective agents". Med. Chem. 3 (5), 475479.

Gravina, H. D., Tafuri, N. F. A., Silva Júnior, J. L. R., Fietto, T. T., Oliveira, M. A. N., and Almeida, M. R., (2011): "In vitro assessment of the antiviral potential of trans-cinnamic acid, quercetin and morin against equid herpes virus 1" Research in Veterinary Science, 91, (3), 158-162, 333-512.

Grogan G. (2009): "Practical Biotransformations" John Wiley and Sons, Ltd, UK.

Hoskins, J. A., (1984): "The occurrence, metabolism and toxicity of cinnamic acid and related compounds". J. Applied Toxicology, 4 (6), 283-338.

Hosny, M., and Rosazza, J. P.N., (1999): "Microbial Hydroxylation and Methylation of Genistein By Streptomycetes". Journal of Natural Products. 62 (12), 1609-1612.

Hosny, M. and Rosazza, J. P. N. (2002): "Novel Oxidation of (+)-Catechin by Horseradish Peroxidase and Laccase", Journal of Agricultural and food chemistry, 50(20): 5539-5545.

Hosny, M.,Kajari, D., and John P. N. Rosazza, J. P.N. (2001): "Hydroxylations and Methylations of Quercetin, Fisetin, and Catechin by Streptomyces griseus".Journal of Natural Products.64 (4), 462-465.

Kato, N., E. H., Joung, H. C., Yang, M., Masuda, M. S., and Yanase, H., (1991): "Purification and characterization of aromatic acid reductase from Nocardiaasteroides JCM 3016". Agric. Biol. Chem. 55, 757-762.

Kim, S. J., Bok, S. H., Lee, H. J., Kim, M. K., Lee, Y. B., and Choi, M.S., (2005): "Anticholesterolemic effect of 3,4-di(OH)-phenylpropionic amides in highcholesterol fed rats".Toxicology and Applied Pharmacology, 208, 29-36.

Kuo, I. M., Yeh, D. B., and Pan, B. S., (1999): "Rapid Photometric Assay Evaluating Antioxidative Activity in Edible Plant Material" Journal of Agricultural and food chemistry, 47, 3206-3209.

LuanaDalbem, R., Mariana Costa, M. and Anderson Junger, T., (2012): “Anticancer Properties of Hydroxycinnamic Acids -A Review" Cancer and Clinical Oncology; 1 (2), 109-121.

Maria -Joao, B., P. Nuno Palma, P., Almeida Lu, S., and Soares-da-Silva, P., (2007): "Catechol-O-methyltransferase and Its Inhibitors in Parkinson's Disease", CNS Drug Reviews, 13, (3), 352-379. 
Miles E. A., Zoubouli, P., Calder, P. C., and Phil, D., (2005): "Differential antiinflammatory effects of phenolic compounds from extra virgin olive identified in human whole blood cultures". Nutrition. 21, 389-394.

Natella, F., Nardini, M. Di., Felice, M., and Scaccini, C., (1999): "Benzoic and cinnamic acid derivatives as antioxidants: Structure-activity relation". J. Agric. Food Chem. 47, 1453-1459.

Prateek, S., (2011): "Cinnamic acid derivatives: A new chapter of various pharmacological activities", J. Chem. Pharm. Res., 3(2), 403-423.

Smith, R. V. and Rosazza, J. P. (1982): "Microbial Transformations of Bioactive Compounds" CRC Press, Boca Raton, Florida, USA. Volium II, 10-25.

Taha S., Hamida, M. A., Nadia M. S., Hosny, M., and Dalia A. M., (2011): "A New Flavonoid C-Glycoside from Celtis australis L. and Celtis occidentalis L. Leaves and Potential Antioxidant and Cytotoxic Activities". Sci. Pharm.79, 963-975.

Thimann, K. V., (1969): "The auxins". In: M.B. Wilkins (ed.), Physiology of plant growth and development", pp. 2-45, McGraw-Hill, London.

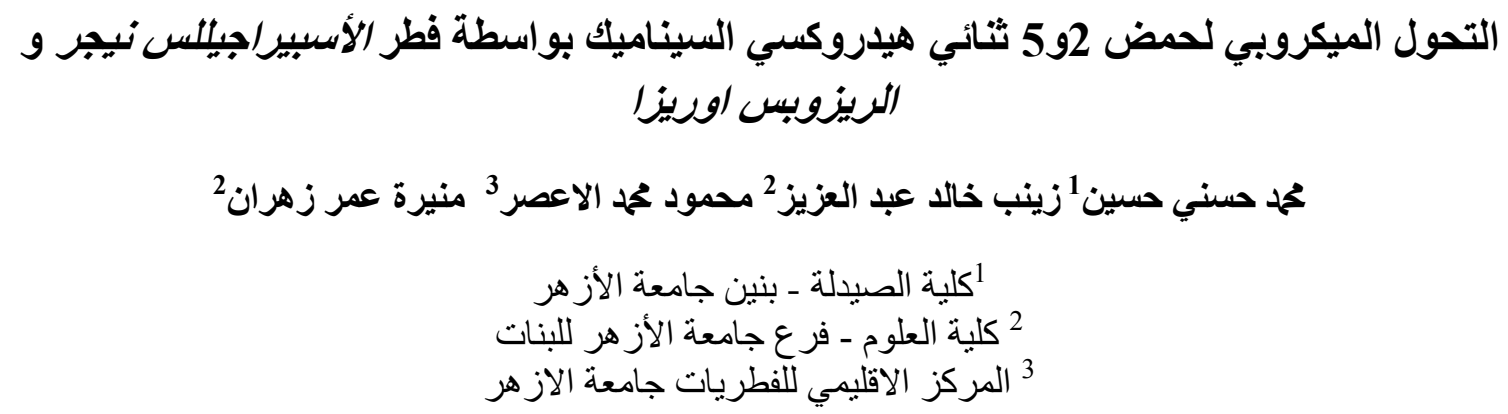

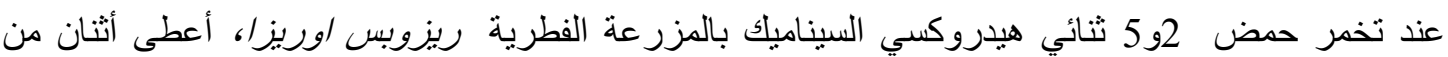

المو اد الأيضية 2و 5 ثنائي هيدروكسي سينامويل الكحول ،

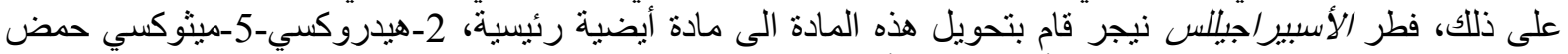

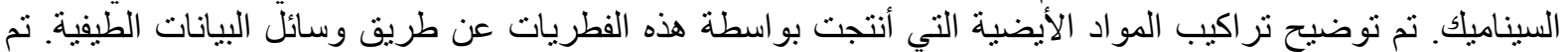

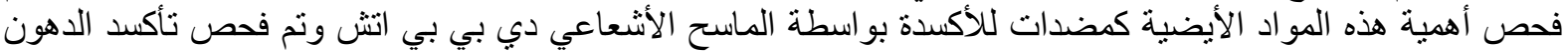
بو اسطة طريقة مو اد التفاعل الحمضية ثيو بار بيتيوير كك باستخدام أنسجة الفئر ان المطحونة بالنسبة لتركية بيبها. 